\title{
O EFEITO DE REALIDADE \\ E A POLÍTICA DA FICC̃̃O*
}

\author{
JACQUES RANCIÈRE \\ TRADUÇÃO DE CAROLINA SANTOS
}

\section{RESUMO}

$\mathrm{O}$ artigo discute elementos do romance realista e questiona as interpretações do papel do "efeito de realidade" oferecidas por críticos literários do século XIX e XX. Para o autor, esse efeito, mais do que mero resultado do "excesso descritivo" característico da obra de escritores como Dostoiévski e Flaubert, revela a abertura social do romance para uma nova sensibilidade, menos aristocrática e mais democrática.

PALAVRAS-CHAVE: Romance realista; efeito de realidade; Roland Barthes; literatura e democracia

\section{ABSTRACT}

The article elaborates on features of the realist novel and questions interpretations of the so-called "reality effect" offered by 19th and 2oth century literary critics. The author claims that this effect, far from beign a mere result of the "descriptive excess" typical of writers such as Dostoiévski and Flaubert, manifests a social opening of the novel to a new sensibility, a less aristocratic and more democratic one.

KEYWORDS: Realist novel; reality effect; Roland Barthes; literature and democracy.

[*] Palestra apresentada no Instituto de Investigação Cultural de Berlim (ICI Berlin) em setembro de 2009 .

[1] Em inglês, "The reality effect". A tradução do título aqui aludida está em Roland Barthes, $O$ rumor da lingua. Trad. Mario Laranjeira São Paulo: Martins Fontes, 2004.

[2] Barthes, Orumordalingua.Trad. Mario Laranjeira. São Paulo: Martins Fontes, 2004, p.181.
Em 1968 Roland Barthes publicou seu texto canônico "O efeito de realidade" retirado do conto de Flaubert "Um coração simples". Ao descrever a sala da casa onde sua personagem vive, o escritor diz que "um velho piano sustentava, sob um barômetro, um monte piramidal de caixas e caixotes" 2 . Obviamente esse barômetro não tem utilidade alguma e o monte piramidal não nos deixa ver nada determinado. Como afirma Barthes, eles "elevam o custo da informação narrativa". Essa avaliação parece estar em consonância com muitas das afirmações de escritores do século XX que denunciavam a futilidade da descrição realista. No "Manifesto do Surrealismo", André Breton descartou a descrição do papel de parede e da mobília do cômodo da usurária em Crime e castigo com umas poucas palavras: "Ele perde seu tempo, porqueeu me recuso a entrar nesse quarto”. No seu prólogo para o romance de Bioy Casares, A invenção de Morel, Borges faz semelhante observação sobre Proust:ele 
diz que existem muitas páginas na sua obra que devemos aceitar como o fazemos com "o insípido e ocioso de cada dia". A questão, então, não é somente sobre o elemento supérfluo na descrição: é sobre a própria descrição. Ela aparece como um excesso que cobre uma falta: o excesso de coisas - mais precisamente o excesso de representação das coisas - substitui um catálogo de clichês para o profuso emprego da imaginação poética; ou ela fica no caminho do enredo e embaralha suas linhas; ou, novamente, ela apaga o jogo de significação literária e opõe sua falsa obviedade à tarefa de interpretação.

O texto de Roland Barthes parece oferecer a fórmula teórica para essas recriminações. Isso significa que a análise estrutural tende a preservar a idéia modernista da obra de arte como desenvolvimento autônomo da sua própria necessidade interna, invalidando a velha lógica da semelhança e da referencialidade. Ela dá uma formulação sistemática para o desprezo modernista pelos objetos inúteis que ficam no caminho da organização estrutural da obra de arte: nada pode ser supérfluo. Agora, como método de análise, o estruturalismo precisa provar que o supérfluo não é supérfluo, que os trabalhos literários que não obedecem ao princípio estruturalista da economia são, contudo, válidos para a análise estrutural. Ao supérfluo deve ser dado um lugar e um estatuto na estrutura. O estatuto que Barthes lhe dá é o estatuto típico que os pressupostos modernistas podem dar ao que está em excesso: o estatuto do sobrevivente. Barthes oferece duas razões para o excesso realista. Em primeiro lugar, ele dá continuidade a uma tradição que data da Antiguidade, a tradição do discurso "epidítico", no qual o objeto da descrição importa menos do que o emprego de imagens e metáforas brilhantes, exibindo a virtuosidade do autor em nome do puro prazer estético. Em segundo lugar, ele tem a função de comprovação. Se um elemento está em algum lugar apesar de não haver razão para a sua presença, isso significa precisamente que o sua presença é incondicional, que ele está presente simplesmente porque está presente. Assim, o detalhe inútil diz: eu sou o real, o real que é inútil, desprovido de sentido, o real que prova sua realidade por sua própria inutilidade e carência de sentido.

Esta comprovação do real parece retroceder a uma oposição que estruturou a lógica da representação. Desde Aristóteles, acreditava-se que a ficção poética consistia em construir um enredo de verossimilhança, uma concatenação lógica de ações, enquanto a História apenas contaria os fatos como eles se deram. Desse ponto de vista, o efeito de realidade rompe com a lógica da representação. Mas ele o faz implementando uma estratégia intermediária: conforme toma o princípio "realista" da história, agarrando-se ao real enquanto real, ele cria um novo tipo de verossimilhança, oposta à clássica. Assim, Barthes afirma que esta nova verossimilhança se torna o núcleo de um fetichismo do 
[3] Ibidem, p.188. real, característico da cultura midiática e exemplificado pela fotografia, pelos noticiários, pelo turismo devotado a monumentos e lugares históricos etc. Tudo isso, conclui Barthes,

[...] diz que o "real" supostamente basta-se a si mesmo, que ébastante forte para desmentir qualquer idéia de "função", que sua enunciação não precisa ser integrada a uma estrutura e que o "ter-estado-lá" das coisas é motivo suficiente para que sejam relatadas 3 .

O que é fascinante nessa sentença é como ela, de fato, se presta a uma guinada que acontecerá dez anos depois, quando Barthes fará do "ter-estado-lá" das coisas o punctum que é a verdade da fotografia e repudiará o conteúdo informativo do studium. Contudo, essa guinada foi possibilitada precisamente pela construção de uma simples oposição entre estrutura ficcional e singularidade absoluta do mero "ter-estado-lá". Creio que uma análise mais detalhada do "monte piramidal de caixas" sobre o velho piano poderia ter oferecido um terceiro termo que talvez rompesse a oposição, simples demais, entre racionalidade funcional da estrutura narrativa e singularidade absoluta. Pretendo mostrar que o "ocioso cada dia" do romance realista é o lugar e o momento de uma bifurcação de momentos muito mais radical do que a bifurcação de caminhos e linhas narrativas apreciada por Borges, e que o foco no efeito de realidade perde de vista a verdadeira ruptura que está no coração da ficção estética. Ele o perde porque a idéia "modernista" de estrutura ainda está de acordo com a lógica representativa que ela finge desafiar, de maneira que ela também deixa de ver a questão política envolvida no excesso "realista".

Aquestão é que, na verdade, a oposição entre a "estrutura" e o "ocioso" ou as "inúteis" notações do "real" traz de volta uma crítica muito mais antiga à ficção realista, que já havia sido feita por muitos críticos, a maioria deles reacionários, no tempo de Flaubert. Esses críticos já haviam chamado a atenção para a enumeração de detalhes, a extensão das descrições que preenchiam seus romances e caracterizavam mais amplamente a literatura contemporânea. Por exemplo, o escritor católico e crítico literário, Barbey d'Aurevilly, contemporâneo de Flaubert, denunciou sua "infinita, eterna, atomística e cega prática da descrição". Como ele mesmo diz,

[... não há um livro ali; não existe essa coisa, essa criação, esse trabalho de arte constituído por um livro com desenvolvimento organizado [...]. Ele escreve sem um plano, indo adiante sem uma visão total preconcebida, não sabendo que a vida, na sua diversidade e na desordem aparente de seus caprichos, édotada de leis lógicas e inflexiveis [...] é um arrastar-se entre o insignificante, o vulgar e o abjeto pelo único prazer do deixar-se estar. 
Essa crítica é evidentemente baseada nos princípios que estruturam a lógica clássica da representação. De acordo com essa lógica, a obra de arte é um tipo definido de estrutura - uma totalidade orgânica, dotada de todas as partes constituintes necessárias para a vida e nada mais; ela deve ter a aparência de um corpo vivo equipado de todos os membros requeridos, unidos na unidade de uma forma, sob o comando de uma cabeça organizadora. O romance "realista" não atende a este requisito. Para Barbey, a questão não é somente a presença de detalhes que em nada contribuem para o funcionamento da estrutura ficcional e apenas interpretam o papel do real afirmando "Eu sou o real". A questão é que as partes não estão subordinadas ao todo; os membros não obedecem à cabeça. $\mathrm{O}$ novo romance realista é um monstro. Ele pertence a uma nova cosmologia ficcional na qual a concatenação funcional de idéias e ações, de causas e efeitos não funciona mais. Nas caixas do novo romancista, todas as coisas estão embaralhadas. $\mathrm{O}$ artista tornou-se um trabalhador. Ele carrega suas sentenças adiante, diz Barbey, da mesma forma que o operário carrega suas pedras adiante num carrinho de mão. A comparação mostra que essa nova cosmologia ficcional é também uma nova cosmologia social.

Outro crítico daquele tempo observou a significação política dessa maneira de escrever: isto é democracia, ele disse, democracia na literatura ou literatura como democracia. A "insignificância" dos detalhes equivale à sua perfeita igualdade. Eles são igualmente importantes ou igualmente insignificantes. A razão para isso é que eles se referem a pessoas cujas vidas são insignificantes. Essas pessoas abarrotam todo o espaço, não deixando margem para a seleção de personagens interessantes e para o harmonioso desenvolvimento de um enredo. É exatamente o oposto do romance tradicional, o romance dos tempos monárquicos e aristocráticos, que se beneficiavam do espaço criado por uma clara hierarquia social estratificada. Sobre este espaço:

Os personagens que corporificam os refinamentos do nascimento, da educação e do coração não deixavam espaço para figuras secundárias, ainda menos para objetos materiais. Essa delicada sociedade via pessoas ordinárias somente através das portas de suas carruagens e o campo somente através das janelas de seus palácios. Isto deixava amplo e fértil espaço para a análise dos sentimentos mais refinados, que são sempre mais complicados e dificeis de decifrar nas almas da elite do que entre as classes mais baixas.

O crítico reacionário revela, com franqueza, a base social da poética representativa: a relação estrutural entre as partes e o todo fundamentava-se numa divisão entre as almas da elite e as das classes baixas. Quando essa divisão desaparece, a ficção se entope de eventos insignificantes e de sensações de todas aquelas pessoas comuns que 
ou não entravam na lógica representativa, ou entravam nos seus devidos lugares (inferiores) e eram representadas nos gêneros (inferiores) adequados à sua condição. Isso é o que a ruptura da lógica de verossimilhança quer dizer. Quando Barthes relaciona essa lógica à velha oposição aristotélica entre poesia e história, ele se esquece de que tal distinção poética formal também era uma distinção política. A poesia era definida como uma concatenação de ações em oposição à mera sucessão histórica de fatos. Mas "ação" não é o mero fato de fazer algo. A ação é uma esfera de existência. Concatenações de ações só poderiam dizer respeito a indivíduos que viviam na esfera da ação, que eram capazes de conceber grandes planos e de arriscá-los no confronto com outros grandes planos e com os golpes do destino. Elas não poderiam se referir a pessoas que estavam confinadas à condição da vida nua, devotadas à única tarefa de sua reprodução infinita. Verossimilhança não é somente sobre que efeito pode ser esperado de uma causa; ela também diz respeito a o que pode ser esperado de um indivíduo vivendo nesta ou naquela situação, que tipo de percepção, sentimento e comportamento pode ser atribuído a ele ou ela.

Posto de outra maneira, a questão da ficção contém dois outros aspectos entrelaçados entre si.A ficção designa certo arranjo dos eventos, mas também designa a relação entre um mundo referencial e mundos alternativos. Isso não é uma questão de relação entre o real eo imaginário. Isso é questão de uma distribuição de capacidades de experiência sensorial, do que os indivíduos podem viver, o que podem experienciar $e$ até que ponto vale a pena contar a outros seus sentimentos, gestos e comportamentos. Esteé o caso do conto ao qual se refere Barthes, "Um coração simples", de Flaubert. O barômetro não está lá para comprovar que o real é o real. A questão não éo real, é a vida,é o momento quando a "vida nua" - a vida normalmente devotada a olhar, dia após dia, se o tempo será bom ou ruim - assume a temporalidade de uma cadeia de eventos sensorialmente apreciáveis que merecem ser relatados. $\mathrm{O}$ ocioso barômetro expressa uma poética da vida ainda desconhecida, manifestando a capacidade de qualquer um (por exemplo, da velha empregada de Flaubert) de transformar a rotina do dia-a-dia na profundeza da paixão, seja por um amante, um senhor, uma criança, seja por um papagaio. O efeito de realidade é um efeito de igualdade. Mas a igualdade não significa somente a equivalência entre todos os objetose sentimentos descritos pelo romancista. Não significa que todas as sensações são equivalentes, mas que qualquer sensação pode produzir em qualquer mulher pertencente às "classes mais baixas" uma aceleração vertiginosa, fazendo-a experienciar as profundezas da paixão.

Esteé o amedrontador significado de "democracia" literária: qualquer um pode sentir qualquer coisa. O objeto dessa paixão pouco importa. Felicité, a empregada de "Um coração simples", é uma serviçal 
perfeita. Mas ela não serve mais como teria servido, de acordo com a lógica hierárquica da verossimilhança. Ela serve com amor, com uma intensidade de sentimento e paixão que excede em muito a intensidade dos sentimentos de sua senhora. Esta intensidade não somente é inútil, ela é perigosa. Alguns anos antes de "Um coração simples", os Irmãos Goncourt, amigos e colegas de Flaubert, haviam publicado a história de uma outra serviçal, Germinie Lacerteux. Germinie também é fanaticamente devotada à sua senhora. Mas ao longo do romance parece que a paixão que faz dela uma serviçal perfeita também faz dela uma mulher capaz de qualquer coisa para servir a suas próprias paixões e a seu próprio desejo sexual até o último estágio de degradação.

Assim, a angélica Felicité e a monstruosa Germinie são irmãs; ambas pertencem à mesma família de Emma Bovary, a família daquelas filhas de camponeses que se provam capazes de sentir qualquer desejo violento, assim como qualquer aspiração ideal.É esta nova capacidade de qualquer um de viver vidas alternativas que coíbe a subordinação das partes ao todo. Não há um livro, diz Barbey, somente retratos pendurados lado a lado. O aristocrático emprego da ação é bloqueado pela democrática coleção desordenada de imagens. Mas o que acontece é uma perda dupla em relação à lógica representativa. Assim como a ação perdeu sua antiga estrutura de uma concatenação de causas e efeitos, a imagem perdeu suas velhas funções de comunicar a qualidade emocional da ação ou mostrar imagens prazerosas durante suas pausas. Ação e percepção, narração e imagem tornaram-se um e o mesmo tecido sensorial de microeventos. Os críticos os condenam como "imagens" que obstruem o caminho do enredo. Mas "imagem" é um termo ambíguo. De fato, as chamadas imagens não nos oferecem muito que ver. (Burke já havia dado a razão para isso: emoções e paixões violentas são mais bem comunicadas por palavras do que por representações visuais, porque palavras não tornam realmente visíveis o que elas descrevem. Este é, de fato, o caso com a forma de violência então desconhecida que consiste na capacidade de qualquer um de experienciar qualquer tipo de sentimento - tanto sublime como abjeto.) Imagens não são descrições do visível. Elas são operadores que produzem diferenças de intensidade. Por sua vez, essas diferenças de intensidade manifestam uma redistribuição das capacidades sensoriais, ou, em termos platônicos, da hierarquia entre almas de ouro e almas de ferro. A democracia no romance realista é a música da igual capacidade de qualquer um de experienciar qualquer tipo de vida. A "imagem" não é adicionada à narração, ela se torna a música da igualdade na qual a oposição entre ação e imagem desaparece.

Esteé, creio, o problema realmente em discussão no chamado efeito de real. A análise de Barthes não leva em consideração a questão política porque, na minha opinião, a idéia de estrutura que sustenta 
[4] Dostoiévski, Crime e castigo, apud Breton, Manifestos do Surrealismo. Trad. Pedro Tamen. Lisboa: Salamandra, 1993, p.19. No segundo, Barthes, op.cit., apud Breton,ibidem. sua investigação sobre o estatuto do "real" na literatura está de acordo com a idéia de estrutura implicada na lógica representativa: a estrutura como arranjo funcional de causas e efeitos que subordina as partes ao todo. A análise estrutural, para ele, deve dar conta de "toda a superfície do tecido narrativo" e designar para cada unidade narrativa um lugar na estrutura. Portanto, o analista "estruturalista" se depara com o mesmo escândalo que os campeões da poética representativa: notações descritivas que não desempenham função alguma e assim "elevam o custo da informação narrativa". A argumentação é exatamente a mesma: o que não tem função na estrutura só pode ser entendido como uma afirmação insistente do real como real. Existem somente a estrutura e o resíduo. Barthes identifica o último como um novo tipo de verossimilhança, a afirmação tautológica do real como real. Mas creio que a crítica dos campeões reacionários da velha verossimilhança via com mais acuidade o que estava em jogo: a invasão da "democracia", diziam eles: uma nova realidade social "insistente" implodindo toda estrutura adequada do enredo, qualquer concatenação correta das ações. Este é o ponto: Barthes analisa o "efeito de real" da perspectiva "modernista", igualando modernidade literária, e seu significado político, com a purificação da estrutura do enredo, descartando as imagens parasíticas do "real". Mas a literatura como configuração moderna da arte de escrever é justamente o oposto: ela é a supressão das fronteiras que delineiam o espaço dessa pureza. O que está em jogo neste "excesso" não é a oposição do singular e da estrutura, é o conflito entre duas distribuições do sensível.

Os críticos do século XIXviam uma relação direta entre a democracia vista como a "igualdade de condições" de Tocqueville e a "proliferação realista de detalhes supérfluos". Mas a ligação entre democracia política e democracia literária é muito mais complicada. Eé essa complexidade que está refletida nas tensões da ficção. A tensão entre "ação" e "descrição" não somente opõe a literatura moderna e as regras da velha poética, ela também reside no coração da ficção literária moderna. A questão do "excesso descritivo" indica essa tensão interna. Pretendo mostrá-la, trazendo de volta uma das críticas que mencionei no início: a crítica de André Breton à descrição de Dostoiévski do cômodo da usurária. Primeiramente, menciono sua citação, depois seu comentário:

O pequeno quarto em que o jovem entrou, com papel amarelo forrando as paredes, vasos de gerânio e cortinas de musselina nas janelas, estava naquele instante intensamente iluminado pelo poente... Mas nada havia de especial no quarto. O mobiliário, todo de madeira amarela e muito velha, era constituído de um sofá, um toucador com espelho disposto entre as janelas, cadeiras junto às paredes, e ainda uns dois ou três quadros baratos em molduras amarelas, representando senhoras alemãs com pássaros nas mãos - eis todo o mobiliário4. 
Não quero admitir que a mente esteja disposta a se ocupar desses assuntos, mesmo que de forma errática. Pode-se dizer que esta descrição escolar tenha o seu lugar, e que naquele ponto do livro o autor tem as suas razões para mesubmeter a ela. Oque écerto éque ele perde seu tempo, porque eu me recuso a entrar nesse quarto5.

Mas a recusa a entrar no quarto deixa de lado a questão crucial: o que "seu quarto" significa, ou de quem é "esse quarto"? É disso que trata a descrição de Dostoiévski. Na verdade, ele descreve dois quartos em um. Significativamente André Breton pulou, na sua citação, duas sentenças que constituíam essa dualidade. Cito toda a passagem:

O pequeno quarto em que o jovem entrou, com papel amarelo forrando as paredes, vasos de gerânio e cortinas de musselina nas janelas, estava naquele instante intensamente iluminado pelo poente. "Quer dizer que no dia o sol também iluminará desse jeito!..." - passou pela mente de Raskólnikov como que por acaso, e ele percorreu tudo no quarto com um olhar rápido, querendo, dentro do possível, estudar e fixar na memória a disposição dos objetos. Mas nada havia de especial no quarto. O mobiliário, todo de madeira amarela e muito velha, era constituido de umsofá, um toucador comespelho disposto entre as janelas, cadeiras junto às paredes, e ainda uns dois ou três quadros baratos em molduras amarelas, representando senhoras alemãs com pássaros nas mãos - isso era tudo ${ }^{6}$.

O próprio Dostoiévski diz que a descrição é inútil. Mas ele também explica por que ela é inútil: porque o inventário da mobília não desempenha o papel que Raskólnikov lhe atribui. Ele passa o olho pelo cômodo com o intuito de mapear a cena do assassinato que está planejando. Mas não há "nada especial" no cômodo, nada que valha a pena incluir no esquema do assassinato planejado. O que sobra, portanto, é "um outro" cômodo, o cômodo que ele primeiramente notou, um cômodo "impressionista" que é feito de retalhos de cor: papel amarelo, cortinas de musselina e o brilho do poente, produzindo um brilho intenso na sua mente: "Quer dizer que no dia o sol também vai estar iluminando desse jeito!...”. Este último comentário é, em algum grau, absurdo: como vamos saber se o dia do assassinato será ensolarado ou não? Precisamente, não é questão de saber. O cômodo do assassinato, o cômodo onde ele acontecerá não é o cômodo ao qual ele olha conscientemente como um criminoso metodicamente planejando seu ato. É o cômodo da alucinação. De fato, o assassinato acontecerá na forma de uma alucinação provocada por um acesso de febre.

Assim, não é verdade que a descrição obstrua o curso da ação. Em vez disso, ela o divide. A aparente banalidade da descrição revela uma dualidade do cômodo que, por sua vez, revela uma divisão no núcleo
[5] Barthes, op. cit., apud Breton, ibidem.

[6] Fiódor Dostoiévski, Crime e castigo. Trad. Paulo Bezerra. São Paulo: Editora 34, 2001, p. 24. 
da própria ação. Como é sabido, Raskólnikov planejou o assassinato a partir de uma teoria racional sobre a sociedade: pessoas pobres e talentosas, como ele, podem se valer de métodos extraordinários para sair de suas misérias e permitir que a sociedade se beneficie de suas capacidades. Ele tem um modelo, Napoleão, o filho de uma obscura família plebéia que se tornou Imperador dos franceses e senhor da Europa. Assim, ele racionaliza o assassinato de acordo com uma racionalidade estratégica de meios e fins. Mas a racionalização sobre o melhor ato não resulta numa capacidade de tomar uma decisão racional e de implementá-la a sangue frio. Ao contrário, ele só consegue executá-la num acesso de febre. A assim chamada "superficialidade" da descrição é a encenação dessa divisão interna. O novo enredo literário, o enredo dos tempos da democracia, separa a ação de si mesma. O insucesso do modelo estratégico caracteriza de uma vez a estrutura do romance realista e o comportamento de seus personagens. A ruína do paradigma aristocrático/representacional também implica a ruína de uma certa idéia de ficção, ou seja, certo padrão de vinculação entre pensar, sentir e fazer.

Gostaria de ilustrar este ponto comentando um estranho episódio de um romance que nos apresenta um irmão mais velho do Raskólnikov de Dostoiévski: Julien Sorel, de Stendhal. Julien Sorel, o personagem principal de O Vermelho e o negro, é filho da Revolução Francesa, admirador de Napoleão que utiliza todos os meios para sair da sua condição inferior. Dessa maneira, o leitor do romance que segue os eventos da sua vida pessoal é também apresentado ao jogo das relações de poder que constituem a sociedade pós-revolucionária. É por isso que Erich Auerbach, no seu livro Mimesis, vê o romance como um passo importante no progresso da representação da realidade na literatura ocidental. Ele inicia o realismo moderno que sugere que o homem está envolvido numa realidade política, econômica e social em permanente evolução. Mas para enfatizar essa idéia de "realismo", Auerbach teve que esquecer as esquisitices do enredo. No final do romance, Julien está na cadeia e espera uma sentença de morte por ter atirado na sua antiga amante, que o havia denunciado ao pai de sua nova amante. Esta última e um amigo estão movendo mundos e fundos para salvar a vida de Julien. Mas ele pede que não o atormentem com "esses detalhes sobre a vida real". Ele quer viver somente a vida da imaginação.Assim, ele passa seus dias fazendo nada, andando pelo terraço da prisão fumando charutos:

Defato, pensava, parece que meu destino é morrersonhando. Um ser obscu-

[7] Stendhal, O vermelho e o negro. Trad. Raquel Prado. São Paulo: CosacNaify, 2003. ro como eu, certo de ser esquecido em menos de quinze dias, seria um tolo, devo confessar, se fizesse muito drama... É inacreditável, contudo, que eu não tenha conhecido a arte de gozar a vida senão depois de ver seu fim tão próximo ${ }^{7}$. 
Já não há aqui uma "descrição" que interrompe o curso da ação. Julien decide viver somente a vida da imaginação, mas não há imagem que expresse esta vida da imaginação. Aquilo que bloqueia a ação é a divisão no próprio coração da "vida". Na prisão Julien descobre a "arte de gozar a vida". Esta "descoberta" tardia não somente contradiz o caráter do jovem ambicioso. Ela também contradiz a ciência com a qual o romancista havia construído seu romance como uma viagem através das redes de relacionamentos e intrigas sociais. Durante toda a narrativa, Julien calculou todas as suas atitudes, e o romancista adicionou aos seus cálculos as explicações que surgiam da sua própria ciência das relações sociais e da psicologia individual. O curso do enredo coincide com o desenvolvimento daquelas intrigas. Mas, no último momento, o enredo se divorcia da lógica das intrigas. O tiro é a primeira ação do herói que não foi decidida segundo um cálculo. Em vez disso, ele diz adeus a todos os cálculos e coloca o herói num espaço e tempo que já não têm a ver com o espaço e tempo das ambições e das expectativas, um espaço e tempo devotados a fazer nada, a não ser "gozar a vida".

Com o intuito de compreender o que está em jogo neste venturoso "fazer nada", que põe um final na carreira do plebeu ambicioso, proponho conectá-lo a outro "fazer nada", formulado num texto bem diferente, um texto filosófico alemão. Dois anos antes da publicação do romance de Stendhal, Hegel comentou, nas suas lições de estética, dois quadros de Murillo que representam garotos pedintes numa rua de Sevilha. Um deles mostra uma mãe catando piolhos da cabeça de um garoto enquanto ele silenciosamente mastiga seu pão. O outro mostra dois meninos maltrapilhos comendo uvas e um melão. A atenção que o filósofo dedica a essas "pinturas de gênero" que representam o cotidiano de pessoas das classes baixas ilustra a inversão da lógica hierárquica do regime representativo. Mas Hegel não se satisfaz com meramente afirmar que todos os temas são equivalentes. Em vez disso, ele faz uma forte conexão entre a qualidade da pintura de Murillo e a atividade daqueles pequenos pedintes, uma atividade que consistia em nada fazer nada e com nada preocupar-se. Eles mostram, ele diz, uma absoluta falta de preocupação com a realidade exterior, uma liberdade interna em meio a essa realidade externa que é exatamente o exigido pelo conceito do ideal na arte. Agachados, eles gozam de um tipo de bem-aventurança que os torna quase deuses olímpicos.

Os quadros dos meninos pedintes que um príncipe comprou, na "era representativa", como ilustrações pitorescas das maneiras de ser das pessoas das classes baixas, agora expressa uma nova qualidade estética, a capacidade de "nada fazer" e preocupar-se com nada, a aptidão ao ócio que pertence aos deuses olímpicos. Na sua descrição, Hegel provavelmente tinha em mente as Cartas sobre educação estética da humanidade de Schiller e sua evocação das "perenemente satisfeitas" 
[8] Friedrich Schiller, Cartas sobre a educação estética da humanidade. Trad. Roberto Schwarz. São Paulo: EPU, 1991, p. 93. divindades do Olimpo, que os escultores gregos haviam representado "libertados das peias de qualquer finalidade, dever ou preocupação". $\mathrm{Na}$ descrição de Schiller, a Juno Ludovisi "repousa e habita em si mesma, uma criação auto-suficiente, que não cede nem resiste, como se estivesse para além do espaço. Não há força, aí, que lute contra forças, nem carência em que pudesse irromper o tempo" ${ }^{\prime}$. Hegel atribui aos meninos pedintes esta "ociosidade" da divindade que nem cede nem resiste. Mas também é a mesma "ociosidade" que o personagem de Stendhal descobre: o estado no qual "nenhum força luta contra forças", ao passo que toda sua carreira, toda a carreira do plebeu que quer conquistar um espaço na sociedade, havia sido uma questão de colocar força contra força.

Mas se aos jovens pedintes despreocupados e ao ambicioso plebeu pode-se oferecer o mesmo benefício do "ócio" olímpico,é porque o ócio que Schiller e Hegel atribuem aos deuses do Olimpo era ele mesmo uma invenção plebéia, uma marca de uma forma plebéia de inversão estética. O estado no qual não há nem concessão nem resistência, no qual nenhuma força luta contra forças, tem um nome - em francês, se chama rêverie. No final de sua vida, o filho de um artesão, um escritor que foi grande influência para Schiller e Kant e para Stendhal também, chamado Jean-Jacques Rousseau, escreveu "Os devaneios do caminhante solitário". Um desses devaneios é dedicado a descrever os dias ociosos que ele passou numa pequena ilha na Suíça, depois de ter sido condenado pelo parlamento francês e ameaçado por uma multidão na Suíça. Esta ilha, ele diz, era como uma prisão na qual gostaria de ter passado o resto da sua vida. Seu tempo lá era parcialmente dedicado a colher plantas, parcialmente dedicado a fazer nada, passando horas deitado num pequeno barco deslizando pelas águas do lago, apenas gozando do simples sentimento de existência, sem preocupação, ou, em outras palavras, o farniente. O farniente do devaneio não é preguiça. Preguiça é o vício do mau trabalhador. O ócio é a virtude daqueles que não precisam se preocupar com trabalhar. Vale lembrar da crítica de Borges ao "cotidiano ocioso" que invade a literatura com Balzac, Flaubert ou Proust. Mas este ócio não é a superficialidade que perniciosamente invadiu a literatura. Foi a inversão da distribuição das temporalidades sociais que fez com que a literatura se tornasse possível. Na velha distribuição do sensível, não havia o "cotidiano ocioso" para o plebeu; o cotidiano significava trabalho ou preguiça. Podemos colocar de outra forma: a distribuição tradicional do sensível opunha o reino da ação aristocrática ao reino da fabricação plebéia. O "fazer nada" do plebeu é a inversão da oposição entre agir e fazer. Qualquer um pode gozar do estado ocioso do devaneio. Esta nova qualidade delimita uma nova esfera de experiência estética (apesar de Bourdieu, o "desinteresse" de Kant deve muito mais ao 
devaneio plebeu do que ao distanciamento aristocrático. Ele também delimita um novo regime de identificação da arte). Um dos principais aspectos desse regimeé a quebra das velhas estruturas de performance narrativa. O assim chamado "efeito de realidade", o foco no "inútil" e "ocioso" cotidiano, primeiro significa essa quebra, esta separação no coração da performance narrativa. As palavras são excessivas por causa desse excesso, que é constituído pela entrada dos filhos de artesãos e camponeses num novo mundo da sensibilidade - o reino da paixão selvagem e do ócio também.

Esta quebra estética está no coração da literatura e da política da literatura. Ela também separa democracia estética, e marcadamente democracia literária, da democracia política. É disso que as estranhezas do romance de Stendhal dão testemunho. Para o plebeu - e para o enredo que conta sua ascensão e queda - a igualdade parece estar dividida desde o começo. De um lado, a igualdadeéo ajuste adequado da capacidade do plebeu a uma posição que lhe é recusada. É um fim que ele quer obter opondo força contra força e usando um conjunto de meios apropriados. De outro lado, a igualdadeé uma nova modalidade da experiência perceptiva que ele pode aproveitar imediatamente, sob uma condição: dizendo adeus ao jogo das forças opostas, ou ao jogo do fim e dos meios. No fim, Julien Sorel desiste de todos os esquemas que havia tramado para conquistar um lugar na sociedade. Ele transforma sua prisão na ilha da prisão metafórica de Rousseau, um lugar para desfrutar o puro sentimento de existência. A mulher que ele tentou matar logo o visitará na prisão e eles se apaixonarão novamente; ele reviverá com ela os únicos momentos felizes da sua vida pregressa: momentos dedicados ao desfrute da existência como tal ou, em outros termos, ao compartilhamento da igualdade sensorial. Mais uma vez, isso não é somente uma questão de personagens ficcionais. Éuma questão deestrutura ficcional.O momento de perfeito júbilo do personagem é aquele em que a lógica do enredo, identificando a concatenação causal das ações narrativas com o jogo das intrigas sociais, colapsa. Como a estrutura ficcional de concatenação de fins e meios ou causas e efeitos tende a identificar-se com a luta das forças sociais, ela é mutilada por uma força de inércia. Em O vermelho e o negro, a força de inércia é a força do devaneio plebeu contra as hierarquias sociais. Mas a divisão da lógica da ação não é específica de um romance. (A mesma coisa acontece em outro grande romance de Stendhal, $A$ Cartuxa de Parma, no qual o herói não mais é o filho de um artesão, mas um jovem aristocrata.) A divisão no coração da ação diz respeito, geralmente, ao enredo estético, à construção de enredos ficcionais dentro da lógica estética. Não é coincidência, creio, que o primeiro autor a trazer ao palco o fracasso da estratégia tenha sido, também, o pensador da condição estética, Schiller, ao mostrar, na trilogia de Wallenstein, no caráter 
inaudito deste general, o arquétipo de um homem de ação e decisão, que é incapaz de agir até que a ciência do astrólogo lhe dite a ocasião adequada. No fim, ele é forçado a agir na pior situação. Depois dele, o enredo do estrategista onipotente condenado à impotência assumiu uma multiplicidade de figuras. Nos anos de 1830, Balzac imaginou uma associação de treze conspiradores que sabiam todos os segredos e controlavam a máquina social. Esses conspiradores acabaram fracassando em todas os seus intentos. Balzac nos oferece uma estranha razão para os seus fracassos. Diz ele: "já que podiam fazer qualquer coisa na sociedade, não se importavam em ser algo nela”. Trinta anos depois de Balzac, Tolstói apresentou, no palco maior da história, o fracasso do modelo estratégico - ou napoleônico - de ação. Os generais crêem estar alcançando seus grandes planos ao disporem de suas tropas no campo de batalha de acordo com suas estratégias. Mas o sucesso ou o fracasso depende de acasos aleatórios; depende de uma multiplicidade de pequenas causas interconectadas que nenhum estrategista consegue dominar. É por isso que o melhor general, Kutuzov, cochila enquanto os demais oficiais discutem as estratégias. Dez anos depois, o ciclo de vinte livros de Émile Zola pretendeu oferecer o relato científico da ascensão de uma família plebéia, identificada à ascensão da sociedade democrática moderna e à neurose moderna. Mas, no último livro do ciclo, todo edifício da ciência desaba: os registros dos cientistas demonstrando como as leis da hereditariedade determinavam essa evolução são queimados e substituídos, nas prateleiras, pelas roupas de um bebê, a incestuosa criança do cientista, simbolizando o insistente triunfo da vida, que aspira a nenhuma finalidade.

Assim, o excesso realista não tem nada a ver com a ostentação burguesa da riqueza e da confiança no reino da Burguesia que alguns autores ali detectaram. O que está no seu coração é muito mais a confusão introduzida quando o excesso de paixão e o vazio do devaneio são apropriados pelas almas das classes baixas. É por isso também que ele não tem muito a oferecer à interpretação contrária, que lhe dá crédito por seu senso progressivo do movimento histórico. De acordo com Auerbach, o romance realista faz com que destinos individuais coincidam com a sabida representação das forças sociais e políticas modernas. Acredito que seja bem o contrário: ele demonstra a impossibilidade da coincidência, a disjunção entre saber e agir, fazer e ser. Os caminhos literários da igualdade se divorciam dos caminhos políticos.

Mas, por outro lado, os enredos partidos da literatura nos indicam a disjunção no coração dos esquemas gerais de evolução histórica e de política revolucionária. Quando o jovem Marx opõe a "revolução humana" à revolução "meramente política", ele está dando continuidade à descoberta de uma igualdade "sensorial" quevai além da transformação das instituições governamentais. Mas quando ele prega a ação revolu- 
cionária baseado na existência de uma classe de homens inteiramente despossuídos de sua humanidade, ele se distancia das formas deemancipação dos trabalhadores que afirmam sua capacidade de gozar aqui e agora um mundo de igualdade perceptiva. A decisão política parecia ser corroída pela igualdade estética, pela capacidade plebéia de "fazer nada". É por isso que Marx se dedicou a aniquilar este "fazer nada" mediante a afirmação de uma privação radical ou de uma nulidade radical, a nulidade da classe que não tem nada a perder a não ser seus grilhões. E ele atribuiu à ciência o poder de sair dessa nulidade. Mas a resposta da ciência da estrutura social às demandas da ação revolucionária se provou tão problemática quanto a ciência do astrólogo de Wallenstein. A revolução supostamente aconteceria como conseqüência da contradição social baseada no conhecimento da concatenação de causas e efeitos que estruturam a exploração e a dominação. Porém, o processo pelo qual o conhecimento chega ao ponto no qual ele pode determinar a ação adia indefinidamente este ponto. $O$ momento em que o socialismo científico atou o futuro comunista ao desenvolvimento intrínseco das forças produtivas é também o momento em que ele se divorciou das teorias que designavam um objetivo para a vida e davam às ciências a tarefa de conhecer este objetivo e determinar os meios de alcançá-lo. "A vida não quer nada", este é o segredo niilista que destrói desde dentro as narrativas científicas otimistas do século XIX.A ciência marxista sabia, de fato, como lidar com esse segredo. Ela o traduziu nos termos de uma estratégia de fins e meios e da expectativa do momento certo. Ela explicou que a marcha para o socialismo não poderia antecipar o desenvolvimento do processo, que ela não poderia impor seus desejos ao curso das coisas. Mas, por debaixo da idéia de adaptação científica ao movimento da vida, havia o sentimento mais profundo de que tal movimento levava a lugar nenhum e que a vontade de mudar a vida não dependia de um processo objetivo. É por isso que o rigor científico teve que inverter-se, afirmar-se como a mera necessidade do rompimento violento que impõe uma direção ao infinito movimento da vida produtiva. A revolução tinha que ser indefinidamente adiada ou ser levada a cabo com uma prestidigitação, exatamente como o tiro de Julien Sorel. A linha reta de ação pensada como conseqüência de uma vontade de conhecimento estava quebrada.

Não quero me demorar nessa questão. Vou apenas aproveitar algumas conclusões das minhas análises sobre a idéia de modernidade artística que sustentou a elaboração do conceito de efeito de real. Essa elaboração impôs uma idéia de modernidade artística como uma estratégia de subtração, rejeitando o excesso realista das coisas junto com as limitações da semelhança. A pintura abstrata tornou-se o emblema dessa idéia. Creio que essa análise erra o alvo. O centro do problema do realismo não era o excesso de coisas, mas a quebra com 
a lógica da ação, a autocontradição da lógica causal. Nem a resposta artística nem a resposta política a essa autocontradição poderia ser encontrada em uma estratégia de subtração. Ao contrário, o que ela requeria era uma estratégia de adição, excedendo o excesso realista, o que significa dizer trazendo à completude a auto-anulação da lógica causal. O que essa completude implicava era uma forma de coexistência das experiências sensoriais que absorvesse tanto o excesso da paixão plebéia como o excesso do devaneio plebeu, uma forma de conexão universal das experiências libertadas de qualquer enredo de causalidade. Isto pode ser ilustrado, creio, pela equivalência de todos os movimentos em Homem com uma câmera, de Dziga Vertov. A linha de produção na fábrica e os gestos de um engraxate na rua, o trabalho de um mineiro e o fazer as unhas num salão de beleza são representados como manifestações equivalentes de energia que o filme conecta uma à outra, assim como os empregados da empresa telefônica continuam a conectar novos interlocutores quando constantemente ligam e desligam os fios. Como se sabe, esse trabalho obedece a um lema aparentemente simples: nenhum enredo, somente a realidade. Mas não devemos nos enganar em relação a essa oposição. Ela não quer dizer que a arte deve representar a realidade e somente a realidade. Ela significa: sem arte, não há representação da realidade. O cinema não é uma arte que representa a realidade ao público. É uma forma de ação que conecta todas as formas de ação: a ação de lavar os cabelos, a ação de extrair carvão, a ação de filmar, colar e copiar, a ação de ver etc. Esta conexão universal dos movimentos cria uma nova percepção na qual a distinção entre realidade e representação desaparece junto com a distinção entre arte e vida. Tudo é ação: não há "fazer nada"; ainda assim, ao mesmo tempo, a ação é libertada da sua dependência dos fins, das vontades e estratégias. Homem com uma câmera é uma sinfonia de movimentos, todos iguais, não importando o fim que eles persigam: produção, consumo, jogo ou simulacro. A conexão dos movimentos os liberta não só das suas solidões, mas também das suas dependências de vontades específicas. As máquinas da indústria socialista e os truques dos mágicos expressam o mesmo ritmo compassado da vida. O cinema cria, portanto, uma forma de comunismo que escapa aos dilemas das estratégias comunistas por inverter o segredo niilista da falta de objetivo da vida. Ele oferece a utopia de um mundo espontaneamente comunista por construir uma percepção comum na qual o movimento orientado da construção socialista está em sintonia com o emprego de todos aqueles movimentos nos quais a vida expressa nada além da sua intensidade igualmente distribuída.

É possível dizer que esseé o privilégio da arte em movimento. Mas o cinema realiza um sonho que ele não inventou: está em acordo com a tentativa whitmaniana de escrever um livro que não é um livro, mas a 
voz que absorve uma inumerável multiplicidade de vozes e formas de experiência, em acordo com a tentativa cubista, futurista e "cubo-futurista" de estilhaçar a superfície da tela em numerosas facetas capazes de expressar todas as intensidades da vida moderna, seja das máquinas seja da dança popular. Isto é, acredito, o que o modernismo historicamente significou a construção de uma sensibilidade de igualdade radical, fazendo da arte e da vida a mesma coisa, uma vez que ele tornou todas as experiências equivalentes e conectou qualquer uma delas a todas elas. Sabemos o que aconteceu com este sonho histórico: ele foi descartado duas vezes. Primeiro, foi reprimido pela exigência do "realismo socialista", que não significava apenas a exigência de que a arte servisse à causa do poder soviético, mas que o realismo esquecesse a sua própria contradição, o que é muito mais problemático. O sonho foi descartado uma segunda vez quando os marxistas ocidentais decidiram escrever o balanço do primeiro descarte e escolheram o modo mais fácil de fazê-lo, que era esquecer o que o modernismo havia significado e reinventar a modernidade com a conquista da autonomia artística. O estruturalismo e a elaboração do conceito de "efeito de real" são os resultados desta reinvenção. Penso que pode ser proveitoso, hoje, reconsiderar essa história.

JACQUES RANCIÈRE é professor emérito de Filosofia e Teoria da Arte da Universidade de Paris VIII (St. Denis).

Recebido para publicação

em 11 de dezembro de 2009 .

\section{NOVOS ESTUDOS}

CEBRAP

86 , março 2010

pp. $75-90$ 